ÉrtSz. = A magyar nyelv értelmező szótára 1-7. Főszerk. BÁRCZI GÉZA - ORSZÁGH LÁsZLó. Akadémiai Kiadó, Budapest, 1959-1962.

HoRger ANTAL 1941. Páros magánhangzóváltozások. Magyar Nyelv 37: 12-16.

MNSzt. = Magyar nemzeti szövegtár. Elektronikus adatbázis, a mai magyar írott köznyelv általános célú reprezentatív korpusza. MTA Nyelvtudományi Intézet, Budapest. http://corpus.nytud.hu/ mnsz/ (2018. 05. 16.)

MTSzt. = Magyar történeti szövegtár. MTA Nyelvtudományi Intézet, Budapest. http://mnsz.nytud. $\mathrm{hu} /(2018.05 .16$.

MNyA. = A magyar nyelvjárások atlasza 1-6. Szerk. Deme LÁszLó - IMrE SAMU. Akadémiai Kiadó, Budapest, 1968-1977.

Nszt. = A magyar nyelv nagyszótára 1-[6]. Főszerk. ITTZÉS NÓRA. MTA Nyelvtudományi Intézet, Budapest, 2006-[2016].

PAIS DeZső 1958. Az egy számnév meg az így határozószó. Magyar Nyelv 54: 52-61.

PÁvel Ágoston 1976. Válogatott tanulmányai és cikkei. Szombathely, Vas megye Tanácsa Végrehajtóbizottsága.

PÁvel ÁGOSTON 1986. Válogatott müfordításai és versei. Szombathely, Vas megye Tanácsa Végrehajtóbizottsága.

STULLI, JOACHIM 1801. Lexicon latino-italica-illyricum ditissimum, ac locupletissimum, in quo adferentur usitatiores, elegantiores, difficiliores earundem linguarum phrases, loquendi formulae, ac proverbia $1-2$. Buda.

ÚMTsz. = Új magyar tájszótár 1-5. Főszerk. B. LŐRINCZY ÉvA. Akadémiai Kiadó, Budapest, 19792010.

VégSz. = A magyar nyelv szóvégmutató szótára. Szerk. PAPP FERENC. Akadémiai Kiadó, Budapest, 1969.

Weöres Sándor 1964. Tüzkút. Magvető Kiadó, Budapest.

Weöres Sándor 1970. Egybegyüjtött írások 1-2. Magvetö Kiadó, Budapest.

Weöres Sándor 2009-2013. Egybegyüjtött költemények 1-3. Helikon, [Budapest].

Weöres Sándor 2013. Elhagyott versek. Helikon, [Budapest].

www-1 = https://prom.ua/Varenichnitsa.html (2018. 05. 16.)

www-2 = https://tiu.ru/Varenichnitsa.html (2018. 05. 16.)

BÜKY LÁSZLÓ

Szegedi Tudományegyetem

\title{
Emészt és enyészik
}

Két ismeretlen vagy bizonytalan eredetü mai magyar igénk összekapcsolását, tövük közös voltának valószínüsítését kísérlem meg itt. Egyik a csak tárgyas igeként használt emészt, megemészt '(eledelt élő szervezet) feldolgoz/felhasznál', átvitt értelemben '(elme) megbirkózik (valamilyen gondolattal v. érzelemmel); gyötör'; emészti magát 'gyötrődik', elemészt ' (el)pusztít', a másik a nem tárgyas enyész-: (el)enyészik 'eltünik, beivódik; (nap) lenyugszik; (el)pusztul'. Az ötletet egy törökkel rokon mongol ige, singge- 'emésztődik; enyészik, beivódik; (nap stb.) lenyugszik' és a belőle képzett, tárgyas singgege- '(meg)emészt, magába szív; hagyja/megvárja, hogy a nap elenyésszék', vö. 'to be absorbed into something; to dissolve (in liquid); to be imbibed, saturated; to be digested (of food); to set (of the sun)' (LESSING et al. 1995: 711b), jelentésköre sugallta, ami természetesen csak jelentésbeli párhuzam, 
nem bizonyíték, és ugyanez érvényes a finn hävitä 'elenyészik; eltünik (pl. a nap a hegy mögött), (köd) felszívódik; elvész', hävittä 'elpusztít' párhuzamára (a vogul tēri- igének csak 'pusztul, oszlik, enyészik' jelentését leltem). A kétszótagú mongol szóval szemben egyszótagú török sing- ige jelentése főképp abban különbözik a mongolétól, hogy égitestek lenyugvására nem használatos, vö. 'to sink into (something Dat.), to be absorbed, digested' stb., oszmán-törökben (1) 'to be digested'; (2) 'to sink in; to influence'; (3) 'to be beneficial'; (4) 'to hide oneself' (CLAUSON 1972: 833-834; hasonlóképp DTS. 500b). Tárgyas megfelelöje singür-. A mongol ige kétszótagúsága lehet elsődleges, de eredhet abból, hogy a mongol nyelv névszó végén ugyan ismert, de igető végén általában nemigen türt veláris, és egyáltalán nem alveoláris orrhangot (vö. török ong- 'fakul', mongol

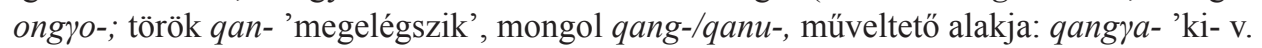
megelégit'; török sun- 'nyújt; nyúlik', mongol sung-/sunu- 'nyúlik', de sungra- 'nyújt').

Az emészt ige és több származéka legalább a 15. század eleje óta van jelen a forrásokban, az enyészik és több származéka a 15. század óta, mint ezt az EtSz., SzófSz., TESz. és az EWUng. (2: 320, 323) tanúsítja. Eszerint az utóbbi igének müveltető, ma nem használatos enyészt származékára már a 14. sz. első feléből van adat (eneztette 'occultasset; elrejtette, eltüntette'), a nem tárgyas tő első adata a század második feléből való (elenÿezek).

16. századiak a következő idézeteim: Károli Gáspár Bibliájában így szól a Példabeszédek 21. fejezetének 25. verse: „A’ restnek kivánsága megemészti ötet.” Malakiás 3, 6: „Mert én UR meg nem változom: ti, Jákób’ fiai, azért nem emésztettek-meg”; Máté 23, 14 : „mert a’ szegény özvegyeknek házokat meg emésztitek hosszú könyörgésnek színe’ alatt”; Jelenések 20,9: „Istentől mennyből tüz szálla-alá, melly meg-emészté azokat [= Gógot és Magógot]". Kecskeméti Vég Mihály 60. zsoltára (1561?; RMKT. 4: 48-50) eképp könyörög: „Nagy szükségemben ne hagyj engemet, / Mert megemészti nagy bánat szívemet.” Temesvári János deák Béla királyról szóló énekében (1571; vö. még Heltai 1575: Krón. 53b: NySz. 1: 633) az emészt ige igekötővel és müveltető-szenvedő képzővel szerepel: „Emleközem arról régen is miként veszet, / Pogán Tatárockal mint meg / emésztettet”. Ugyanebben az énekben igekötő nélkül: „Mind templom, mind váras tủzzel emésztetnéc”. Heltai Gáspár krónikája (1575) a legendás csodaszarvasról írja Kézai nyomán: „Mikoron kedig annyira utánna siettenek vólna a szarvasnak, hogy elérték vólna az európabeli Scíthiát, ott elenyészék előttek a szarvas." (46).

A 17. századi Zrinyi Miklós mindkét igét használja verseiben, többször a tárgyasat, egyszer a nem tárgyas enyész- tövet (vö. ZrínyiSz.). Íme egy példa híres-szép erkölcsi hitvallásából: „Befed az a kék ég, ha nem fed koporsó, / Órám tisztességes csak legyen utolsó. / Akár farkas, akár emésszen meg holló: / Mindenütt felyül ég, a’ föld lészen alsó." Egy másik, az emészt ige emésztetlenség származékszavával: „Az álom sokszor Isten akaratjából vagyon, sokszor csak az étkeknek füstölgő emésztetlenségéből”. Az Adriai tengernek syrenaia (1651) a szigetvári hősről mondja: „Hon az meleg hajnal pirossan fel tetczik, / Hon az sötét estve tengerben enyészik, / Hon az Eszak Tenger magában küszködik: / Hired mindenüt van, s mint nap, ugy tündöklik".

Az Erdélyi magyar szótörténeti tár 1568-ból és 1575-böl idézi a tárgyas enyészt igéből képzett enyésztő (Enyzto [= enyísztő]) 'méregkeverő' igenevet: „,hogy valaki engem Enyztonek mondana”, és „Enyezteo Newel fogtatta volt meg”, 1597-ből pedig az enyész- igét: ,az Kannagiarto vdwara(n) víz werem wala oda enyészet az viz, ne(m) folt az mas vdwaron altal” (SzT. 3: 226) és Borsos Tamás naplójából ennek igekötős alakját 
(1613): „az nyári házban alatt az földön egy igen szép, sokszegü, fejér márványkőből csinált csekme ['szökőkút', vö. török čäšmä 'kút, szökőkút', KAKUK 1973: 105], az kiben huddozott fel az szép víz tizenkét csőből és ismét ugyanott elenyészett" (2: 857). Ugyanott 1793-ból: ,a’ közlebb el enyészett télen”, 1773-ból: elenyészlik (füst), 1830-ból: elenyészt '(ügyet) elsimít', 1840-böl: elenyésztet '(ügyet) elhallgat, elaltat', illetve (2: 858) 1819böl: elenyésztetik 'megszüntettetik; semmissé válik'. L. még emészt 'senyveszt' (3: 168), emésztö 'senyvesztö, elenyésztő', emésztödik 'senyved' (3: 169), elemészt 'megesz; elrongyol; eltüntet' (2: 854), felemésztés 'elemésztődés, sorvadás' (3: 836) stb.

Nyelvjárási szótárainkból álljon itt még néhány érdekes adat. Az Ormánysági Szótárból (OrmSz. 127) valók a következők: emészt 'rágva, felfalva pusztít, mar; szid'. Elemészt [= szidással agyongyötör] a feleségöm ha eszt mökhalli. Mindég asz mondi, ü eszt nem bíri, inkább elemészti magát. Kiemésztnek mindönömbül. Soha vissza nem mén az uráhó, a Dráva feneke emészti mög. Az idő mindönt mögemészt. Emísztelödik 'gyötri magát'.

Négy mondat BÁLINT SÁNDOR szegedi szótárából: Ez a kis eső mingyá elenyészött a födbe (SzegSz. 1: 328), Valami méreggel emísztette el a feleségit (376), Nagyon emíszt a bánat miattad (374), Mindön pénzömet fölemésztötte az operáció (425).

KÁLNÁSI ÁRPÁD cívis szótárából: emíszt (DCSz. 208), elemísztőüdött (188), lassan a tüz is elenyíszik (i. h.), elenyíszlik (i. h.), napenyíszet (619).

BALOGH LAJOS büki szótárából: elemísztëttë magát 'öngyilkos lett' (BükiTsz. 53).

Az ÚMTsz. számos vonatkozó címszava közül idézem a következőket, képzett alakjuk vagy jelentésmeghatározásuk miatt: elemésztödik '< ... víz a földbe > beszívódik' (2: 82), (el)emészkedik 'meghal' (187), elenyészlik 'elenyészik; <gyümölcs> megrothad', elenyészlödik 'elsatnyul' (82), (nap)enyészet, apátfalvi (t)eníszletödik [= enyészletödik] 'enyészik, emésztődik' (193).

Egy lutheránus gyászének kezdősora: „Immár a nap elenyészett.” Egy helvéciai hitvallású téli ének: „Úgy tetszik, halva fekszik a természet, / Mivel tündöklő fénye elenyészett." (ÉK. 400).

Az 1569-ből való erdélyi Enyzto/Enyezteo [=enyísztő/enyésztő] 'elemésztő, méregkeverő' szó is azt sugallja, hogy a két igető, enyész(t)- és emész(t)- valaha azonos jelentésü volt. Valószínü, hogy mai különállásuk szóhasadás eredménye. A magánhangzóközi mássalhangzó-különbséget illetően BENKÖ LORÁND tanár úr hívta fel figyelmemet a fénylik és fémlik szavakbeli ny : m megfelelésre (1. pl. SzT. 4: 9, 1634-böl: ,femlik vala ... kezeben az szekercze”; 1745-ből: „talám sárkány lakik ott, és annak femlik a szeme”; EWUng. 1: 379). Ilyen a hunyó és humó (EWUng. 1: 588), az iszonyú és iszamó (EWUng. 1: 630631) a kanyarodik és kamarodik karamodik (EWUng. 1: 683), valamint a szirony és szirom (EWUng. 2: 1430) esete. L. még kanyaró < török qüzamuq 'vörös kiütéssel járó fertőző betegség' (CLAUSON 1972: 684: kızla:muk > kızamuk 'kanyaró') vagy qaramuq 'konkoly'; csagatájban 'konkoly; egy piros gyümölcs; gyermekbetegség okozta fekete kiütés', oszmán-törökben 'konkoly; vadszilva; kiütés' (1. ClAuson 1972: 660; DTS. 424: qaramuq 'konkoly' és 450: qüzlamuq, qüzamuq 'kanyaró'); vö. TESz. (2: 353); EWUng. (1: 654); ESz. (375); WOT. (1: 489-490; ahol közelebbi csuvas rokon híján, LIGETI LAJost követve a qara 'fekete' szóból származó qaramuq alakot jelöli a kanyaró forrásául).

Hogy a göcseji elemëdik 'eltünik', elemmett 'elmállott' (ÚMTsz. 2: 81) szavak töve idetartozik-e, kérdéses. Az enyekes 'gennyes' szóé (TESz. 1: 769) aligha. Az EWUng. (a TESz. ellenében is) joggal állítja, hogy az enyészik igét aligha lehet az enyh szóból szár- 
maztatni, s hogy az emészt igének az eszik vagy az emik igéből való eredeztetése hangtani nehézségbe ütközik. Hasonló az ESz. ítélete. Az emik 'szopik' igével való rokonítás esetében jelentéstani nehézség is fennáll.

\section{Hivatkozott irodalom}

BükiTsz. = BALOGH LAJOS, Büki tájszótár. Vasi Szemle Szerkesztősége, Szombathely, 2004.

Clauson, Sir Gerard 1972. An etymological dictionary of pre-thirteenth century Turkish. Clarendon Press, Oxford.

DCSz. = KÁLNÁSI ÁRPÁD, Debreceni cívis szótár. A Debreceni Egyetem Magyar Nyelvtudományi Intézetének kiadványai 83. DE Magyar Nyelvtudományi Intézete, Debrecen, 2005.

DTS. = Древнетюркский словарь. Ред. В. М. Наделяев, Д. М. Насилов, Э. Р. Тенишев, А. М. Щербак. Наука, Ленинград, 1969.

ÉK. = Közönséges isteni tiszteletre rendelt Énekes Könyv. Hornyánszky Viktor, Pest, 1806.

ESz. = Etimológiai szótár. Főszerk. ZAICZ GÁBOR. Tinta Könyvkiadó, Budapest, 2006.

EtSz. = Gombocz ZoltÁN - Melich JÁNOS, Magyar etymologiai szótár 1-17. füzet. MTA, Budapest, 1914-1944.

EWUng. = Etymologisches Wörterbuch des Ungarischen 1-2. Hrsg. LoRÁND BENKŐ. Akadémiai Kiadó, Budapest, 1993-1995.

Heltai Gáspár 1575. Krónika az magyaroknak dolgairól. KULCSÁR PÉTER bevezetőjével kiadta KulCSÁr MARGit. Magyar Helikon, Békéscsaba, 1981.

KAKUK ZSUZSA 1973. Recherches sur la langue osmanlie des XVI et XVII siècles. Les éléments osmanlis de la langue hongroise. Akadémiai Kiadó, Budapest.

Károli Gáspár 1590/1794. Szent Biblia. Utrecht.

LESSING, FERDINAND et al. 1995. Mongolian-English dictionary. The Mongolia Society, Bloomington, Indiana.

OrmSz. = Ormánysági szótár. KISS GÉZA szótári hagyatékából szerk. KerESZTES KÁLMÁN. Akadémiai Kiadó, Budapest, 1952.

RMKT. 4. = Régi magyar költők tára 4. Szerk. STOLL BÉLA. Akadémiai Kiadó, Budapest, 1975.

SzegSz. = BÁLINT SÁNDOR, Szegedi szótár 1-2. Akadémiai Kiadó, Budapest, 1957.

SzófSz. = BÁRCZI GÉZA, Magyar szófejtő szótár. Budapest, 1941.

SzT. = Erdélyi magyar szótörténeti tár 1-14. Föszerk. SzABÓ T. ATTILA etc. Kriterion Könyvkiadó etc., Bukarest etc., 1975-2014.

TESz. = A magyar nyelv történeti-etimológiai szótára 1-3. Főszerk. BENKŐ LORÁND. Akadémiai Kiadó, Budapest, 1967-1976.

ÚMTsz. = Új magyar tájszótár 1-5. Főszerk. B. LŐRINCZY ÉVA. Akadémiai Kiadó, Budapest, 19792010.

WOT. = RÓNA-TAS, ANDRÁS - †BERTA, ÁRPÁD. 2011. West Old Turkic. Turkic Loanwords in Hungarian 1-2. Harrassowitz, Wiesbaden, 2011.

Zrínyi Miklós, 1651. Adriai tengernek syrenaia. Kosmerovi Máté, Bécs.

ZrínyiSz. = Zrinyi-szótár. Zrinyi Miklós életmüvének magyar szókészlete. Szerk. BEKE JózSEF. Zrínyi-könyvtár 5. Argumentum Kiadó, Budapest, 2004.

KARA GYÖRGY

Indiana University, Bloomington 